\begin{tabular}{ll|l} 
Case Reports in & \multicolumn{1}{c}{ Case Rep Gastroenterol } \\
\cline { 2 - 3 } Gastroenterology & DOI: 10.1159/000442663 & $\begin{array}{l}\text { ○ } 2016 \text { The Author(s) } \\
\text { Published by S. Karger AG, Basel } \\
\text { www.karger.com/crg }\end{array}$ \\
\cline { 2 - 3 } & $\begin{array}{l}\text { This article is licensed under the Creative Commons Attribution-NonCommercial } 4.0 \\
\text { International License (CC BY-NC) (http://www.karger.com/Services/OpenAccessLicense). } \\
\text { Usage and distribution for commercial purposes requires written permission. }\end{array}$
\end{tabular}

\title{
Usefulness Of Three-Dimensional Printing Models for Patients with Stoma Construction
}

\author{
Tetsuro Tominaga $^{a} \quad K^{2}$ atsunori Takagi ${ }^{b}$ Hiroaki Takeshita ${ }^{a}$ \\ Tomo Miyamoto $^{d}$ Kozue Shimoda $^{d}$ Ayano Matsuo $^{d}$ \\ Keitaro Matsumoto ${ }^{a, b}$ Shigekazu Hidaka ${ }^{a}$ Naoya Yamasaki ${ }^{a, b}$ \\ Terumitsu Sawai ${ }^{c}$ Takeshi Nagayasu ${ }^{a, b}$ \\ ${ }^{a}$ Department of Surgical Oncology, Nagasaki University Graduate School of Biomedical \\ Science, Nagasaki, Japan; ${ }^{b}$ Department of Medical Engineering Hybrid Professional \\ Development Center, Nagasaki University Graduate School of Biomedical Science, \\ Nagasaki, Japan; 'Department of Health Science, Nagasaki University Graduate School of \\ Biomedical Science, Nagasaki, Japan; ${ }^{d}$ Department of Nursing, Nagasaki University \\ Hospital, Nagasaki, Japan
}

\section{Keywords}

Three-dimensional printing $\cdot$ Stoma $\cdot$ Patient education

\begin{abstract}
The use of patient-specific organ models in three-dimensional printing systems could be helpful for the education of patients and medical students. The aim of this study was to clarify whether the use of patient-specific stoma models is helpful for patient education. From January 2014 to September 2014, 5 patients who underwent colorectal surgery and for whom a temporary or permanent stoma had been created were involved in this study. Threedimensional stoma models and three-dimensional face plates were created. The patients' ages ranged from 59 to 81 years. Four patients underwent stoma construction because of rectal cancer, and 1 underwent stoma construction because of colon stenosis secondary to recurrent cancer. All patients were educated about their stoma and potential stomaassociated problems using three-dimensional stoma models, and all practiced cutting face plates using three-dimensional face plates. The models were also used during medical staff
\end{abstract}


conferences to discuss current issues. All patients understood their problems and finally became self-reliant. The recent availability of three-dimensional printers has enabled the creation of many organ models, and full-scale stoma and face plate models are now available for patient education on cutting an appropriately individualized face plate. Thus, threedimensional printers could enable fewer skin problems than are currently associated with daily stomal care.

\section{Introduction}

The number of patients with colorectal cancer has increased in Japan. Therefore, the opportunities for stoma construction have also increased [1]. Patients with a stoma must be able to appropriately care for it on a daily basis. Stomal care includes the ability to cut the face plate of the ostomy bag because a properly sized face plate is necessary to avoid skin aggravation. Thus, patient education regarding stomal care is essential. However, with population aging, stoma management education for both patients and their families is often difficult. Additionally, the length of hospital stay must often be shortened to reduce health care costs, making stoma management education more difficult within a limited time period.

Three-dimensional (3D) printing systems have recently been developed. These systems produce virtual models based on a patient's physical 3D anatomy [2, 3]. Using this technology and specialized software programs, transverse sections are physically reproduced to physical life-sized 3D models of organs. In this study, we evaluated the usefulness of 3D stoma models and face plates for patient education.

\section{Case Report}

Five patients aged 59-80 years who underwent colorectal surgery and for whom temporary or permanent stomas had been created were involved in this study. We created 3D graphics for each stoma with an Artec 3D scanner ${ }^{\circledR}$ (Artec, Luxembourg, Luxembourg) and customized them with Geomagic Free Form ${ }^{\circledR}$ graphics (Geomagic, Cary, N.C., USA). These 3D graphics were entered into an Objet260 Connex ${ }^{\circledR}$ printer (Stratasys, Eden Prairie, Minn., USA) with a stereolithography form. The face plates of the ostomy bags were created using the Geomagic Free Form ${ }^{\circledR}$ graphics to adjust the stoma to the individual. With guidance, patients practiced stoma care using the 3D stoma models. The stoma models were used not only to help the patients to understand their own stoma, but also for medical staff members, who examined problems associated with the stoma. The 3D face plates were used to allow the patients to practice cutting their own plates (fig. 1). Table 1 shows the patients' characteristics. The patients' ages ranged from 59 to 81 years. Four patients underwent stoma construction because of rectal cancer, and 1 underwent stoma construction because of colon stenosis secondary to recurrent cancer. Three cases involved ileostomy (double stomas), and 2 involved colostomy ( 1 double stoma and 1 single stoma). Two patients had difficulty to cut the face plate because of advanced age and comorbidity. Three patients had skin erosion because of stoma trouble. For all 5 patients, stomal care improved due to education using their individual models. We herein present a representative case.

Case 5 was a 64-year-old woman who underwent construction of permanent ileostomy because of rectal cancer. The stoma was caving, which caused soiling and erosion of the surrounding skin. Using a 3D stoma model, medical staff members discussed the stoma- 
associated problems several times and familiarized the patient with the methods of stomal care (fig. 2a, b). We then provided guidance regarding management of the problem and coping techniques. Finally, at the time of discharge, the patient was able to perform stomal care alone.

\section{Discussion}

Various studies found that the use of patient-specific organ models could be helpful for the education of patients and medical students [4-6]. To the best of our knowledge, however, this is the first report of the use of 3D-printed models in the setting of stoma education.

We observed the effectiveness of the models in the present study. Older patients usually have many more comorbidities than younger patients, such as dementia and cerebrovascular disease, which can impair their ability to learn new skills [7-9]. Most of the patients in the present study were older patients. Case 1 was a patient of advanced age with a history of brain infarction and difficulty performing detail-oriented tasks. However, he and his family repeatedly practiced cutting the face plate using 3D face plate models. They finally obtained the necessary skill.

In traditional stomal care, patients cannot directly visualize their own stoma, resulting in a discrepancy in visualization of the stoma between the medical staff and patients. Using 3D models, both the staff and patients are able to understand the shapes and features of the stoma from the same observation point and can thus discuss stoma-associated problems in the same way. The medical staff also used the stoma models in medical conferences to help better understanding of the stoma problems. In case 5, the stoma was at skin level, and personal care was difficult. We created individual models and discussed stoma-related problems in staff conferences. The staff understood the problems and discussed methods of resolution. The patient finally became self-reliant in terms of stomal care.

Furthermore, after discharge from the hospital, the patients could use their 3D models at home or at the outpatient clinic. These models could be useful not only for short-term stomal care, but also for prolonged care.

Although we have emphasized the effectiveness of our 3D stoma models, some limitations should be noted. First, the cost was relatively high (about 100 USD per patient). Additionally, the creation of a 3D model requires several days. However, several low-cost 3D models have recently been developed using low-cost materials or designs, which may solve these problems $[10,11]$. Second, the size of the stoma may change during the perioperative period. In Case 4, the stoma became smaller due to improving postoperative edema. Although it was possible to understand the shape and problems associated with the stoma in this case, it was difficult to practice cutting the face plate using the 3D face plate because it was ill-fitted. Further experience and case conferences are needed to solve an adequate period to create the stoma model.

The recent development of 3D printers has enabled the creation of many organ models, and has made full-scale stoma and face plate models available for patient education on cutting an appropriately individualized face plate. Thus, 3D printers could reduce the skin problems currently associated with daily stomal care. 
Tominaga et al.: Usefulness Of Three-Dimensional Printing Models for Patients with Stoma Construction

\section{Acknowledgement}

We thank Naokado Matsuo for his excellent technical assistance.

\section{Statement of Ethics}

All procedures followed were in accordance with the ethical standards of the responsible committee on human experimentation. Informed consent was obtained from all patients to be included in the study.

\section{Disclosure Statement}

The authors declare no potential conflict of interests with respect to the authorship and/or publication of this article.

\section{References}

1 Alves A, Panis Y, Mathieu P, Mantion G, Kwiatkowski F, Slim K: Postoperative mortality and morbidity in French patients undergoing colorectal surgery: result of a prospective multicenter study. Arch Surg 2005;140:278-283.

2 Garstle TL, Ibrahim AM, Kim PS, Lee BT, Lin SJ: A plastic surgery application in evolution: threedimensional printing. Plast Reconstr Surg 2014;133:446-451.

3 Schneider J: A novel 3D integrated platform for the high resolution study of cell migration plasticity. Macromol Biosci 2013;13:973-983.

4 Flugge TV, Nelson K, Schmelzeisen R, Metzger MC: Three-dimensional plotting and printing of an implant drilling guide: simplifying guided implant surgery. J Oral Maxillofac Surg 2013;71:1340-1346.

5 Chien KB, Makridakis F, Shah RN: Three-dimensional printing of soy protein scaffolds for tissue regeneration. Tissue Eng 2013;19:417-426.

6 Akiba T, Inagaki T, Nakada T: Three-dimensional printing model of anomalous bronchi before surgery. Ann Thorac Cardiovasc Surg 2014;20:659-662.

7 Alves A, Panis Y, Mathieu P, Mantion G, Kwiatkowski F, Slim K: Postoperative mortality and morbidity in French patients undergoing colorectal surgery: result of a prospective multicenter study. Arch Surg 2005;140:278-283.

8 Fielding LP, Phillips RK, Hittinger R: Factors influencing mortality after curative resection for large bowel cancer in elderly patients. Lancet 1989;1:595-597.

9 Turrentine FE, Wang H, Simpson VB, Jones RS: Surgical risk factors morbidity, and mortality in elderly patients. J Am Coll Surg 2006;203:865-877.

10 Zuniga J, Katsavelis D, Peck J: Cyborg beast: a low-cost 3D-printed prosthetic hand for children with upper-limb differences. BMC Res Notes 2015;8:8-10.

11 Olszewski R, Szymor P, Kozakiewicz M: Accuracy of three-dimensional, paper-based models generated using a low-cost, three-dimensional printer. J Craniomaxillofac Surg 2014;42:1847-1852. 
Tominaga et al.: Usefulness Of Three-Dimensional Printing Models for Patients with Stoma Construction
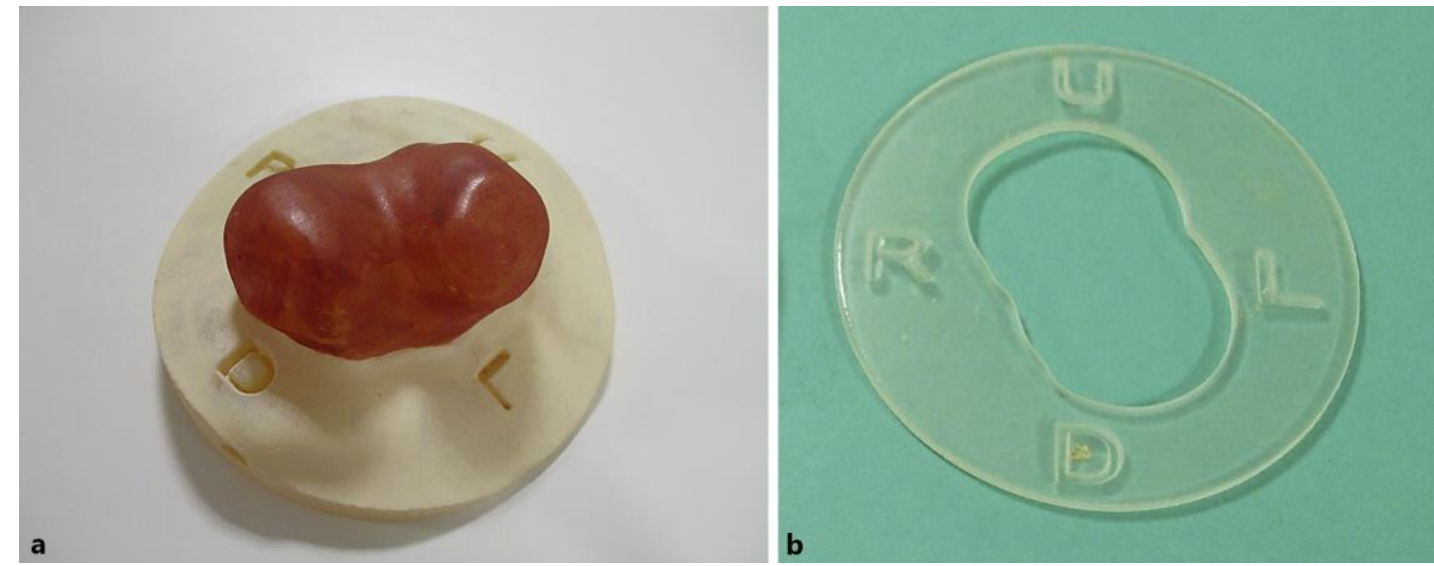

Fig. 1. 3D stoma model (a) and 3D face plate (b) of the ostomy bags were created using Geomagic Free Form ${ }^{\circledR}$ graphics.
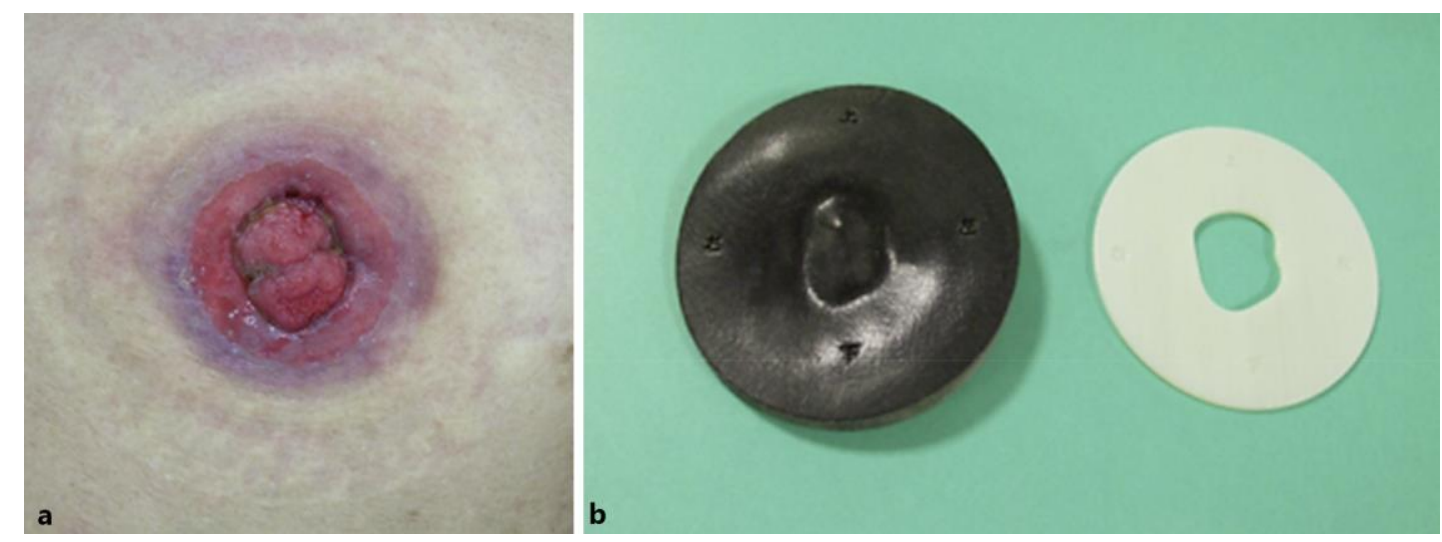

Fig. 2. Case 5. a A double stoma was constructed in the ileum due to rectal cancer. b 3D model and 3D face plate of the patient. 


\section{Case Reports in Gastroenterology}

\begin{tabular}{|c|c|}
\hline Case Rep Gastroenterol & \\
\hline DOI: 10.1159/000442663 & $\begin{array}{l}\text { (c) } 2016 \text { The Author(s). Published by S. Karger AG, Basel } \\
\text { www.karger.com/crg }\end{array}$ \\
\hline
\end{tabular}

Tominaga et al.: Usefulness Of Three-Dimensional Printing Models for Patients with Stoma Construction

Table 1. Patients' characteristics

\begin{tabular}{|c|c|c|c|c|c|c|c|}
\hline Age & Gender & $\begin{array}{l}\text { Original } \\
\text { disease }\end{array}$ & Operation & Stoma type & Location & Problem & Usefulness \\
\hline 81 & M & $\begin{array}{l}\text { colon stenosis } \\
\text { due to } \\
\text { recurrence }\end{array}$ & $\begin{array}{l}\text { stoma } \\
\text { construction }\end{array}$ & $\begin{array}{l}\text { double/ } \\
\text { permanent }\end{array}$ & $\begin{array}{l}\text { transverse } \\
\text { colon }\end{array}$ & $\begin{array}{l}\text { difficult to cut face plate } \\
\text { because of high age }\end{array}$ & practice using face plate \\
\hline 59 & M & rectal cancer & $\begin{array}{l}\text { low anterior } \\
\text { resection }\end{array}$ & $\begin{array}{l}\text { double/ } \\
\text { temporary }\end{array}$ & ileum & $\begin{array}{l}\text { difficult to cut face } \\
\text { plate because of brain } \\
\text { infarction }\end{array}$ & practice using face plate \\
\hline 77 & M & rectal cancer & $\begin{array}{l}\text { Mile's } \\
\text { operation }\end{array}$ & $\begin{array}{l}\text { single/ } \\
\text { permanent }\end{array}$ & $\begin{array}{l}\text { sigmoid } \\
\text { colon }\end{array}$ & skin erosion & $\begin{array}{l}\text { discuss the problem } \\
\text { using stoma model in } \\
\text { staff conference }\end{array}$ \\
\hline 66 & $\mathrm{~F}$ & rectal cancer & $\begin{array}{l}\text { low anterior } \\
\text { resection }\end{array}$ & $\begin{array}{l}\text { double/ } \\
\text { temporary }\end{array}$ & ileum & skin erosion & $\begin{array}{l}\text { discuss the problem } \\
\text { using stoma model in } \\
\text { staff conference }\end{array}$ \\
\hline 64 & M & rectal cancer & $\begin{array}{l}\text { stoma } \\
\text { construction }\end{array}$ & $\begin{array}{l}\text { double/ } \\
\text { permanent }\end{array}$ & ileum & $\begin{array}{l}\text { caving stoma skin } \\
\text { erosion }\end{array}$ & $\begin{array}{l}\text { stoma care } \\
\text { education }\end{array}$ \\
\hline
\end{tabular}

